\title{
PENGARUH PENAMBAHAN KARAGINAN DENGAN LEVEL YANG BERBEDA TERHADAP KOMPOSISI KIMIA, KUALITAS FISIK, SENSORIS DAN MIKROSTRUKTUR SOSIS AYAM
}

\section{EFFECT OF CARRAGEENAN ADDITION AT DIFFERENT LEVELS ON CHEMICAL, PHYSICAL, SENSORY AND MICROSTRUCTURE QUALITIES OF CHICKEN SAUSAGES}

\author{
Arif Ismanto* dan Deny Sumarna \\ Agriculture Faculty of Mulawarman University, Samarinda, 75119
}

Submitted: 2 November 2015, Accepted: 15 February 2016

\section{INTISARI}

\begin{abstract}
Berbagai mikroflora yang berada di usus besar manusia secara nyata dipengaruhi oleh serat pangan. Kekurangan serat pangan dalam konsumsi harian manusia berkontribusi terhadap metabolisme gastrointestinal dan penyakit kardiovaskuler. Salah satu sumber serat pangan adalah berbagai jenis rumput laut. Penelitian ini dilakukan untuk mengetahui pengaruh penambahan karaginan pada produk daging restrukturisasi terhadap kualitas produk (komposisi kimia, kualitas fisik, kualitas organoleptik dan mikrostruktur). Penelitian terdiri dari 4 perlakuan yaitu (1) sosis ayam tanpa penambahan karaginan, (2) sosis ayam dengan penambahan karaginan sebanyak $3 \%$, (3) sosis ayam dengan penambahan karaginan sebanyak $6 \%$, dan (4) sosis ayam dengan penambahan karaginan sebanyak $9 \%$. Parameter yang diamati meliputi: komposisi kimia produk (kolagen, lemak, air, protein), kualitas fisik ( $\mathrm{pH}$, keempukan, daya ikat air (DIA), susut masak), kualitas organoleptik (warna, tekstur, rasa, aroma, daya terima) dan mikrostruktur sosis ayam. Data komposisi kimia dan kualitas fisik dianalisis menggunakan Anova dan diuji lanjut menggunakan uji Beda Nyata Terkecil (BNT). Data organoleptik diuji menggunakan Methods Successive Interval (MSI). Hasil penelitian menunjukkan bahwa penambahan karaginan dengan level yang berbeda berpengaruh nyata $(P<0,05)$ terhadap kadar air dan nilai $\mathrm{pH}$. Penambahan karaginan dengan level yang berbeda juga berpengaruh terhadap rasa sosis ayam yang dihasilkan. Penambahan karaginan dengan level yang berbeda tidak berpengaruh pada warna, aroma, tekstur, keempukan, dan daya terima. Analisis mikrostruktur menunjukkan bahwa penambahan karaginan menyebabkan semakin banyak terbentuknya jaringan-jaringan gel.
\end{abstract}

(Kata kunci: Analisis mikrostruktur, Karaginan, Komposisi kimia, Kualitas fisik, Kualitas organoleptik, Sosis ayam)

\begin{abstract}
Various microfloras residing in the human colon are significantly affected by dietary fiber. Shortage of dietary fiber in the human daily consumption contributes to gastrointestinal metabolic and cardiovascular disease. One source of dietary fiber is a type of various seaweeds. This research was conducted to determine the effect of carrageenan addition on restructured meat products quality (chemical, physical, sensory and microstructure). There were four treatments in this experiment, (1) chicken sausages without carrageenan addition, (2) chicken sausage with $3 \%$ carrageenan addition, (3) chicken sausage with $6 \%$ carrageenan addition, and (4) chicken sausage with $9 \%$ carrageenan addition. The parameters observed were chemical composition (collagen, fat, water, protein), physical quality ( $\mathrm{pH}$, tenderness, water holding capacity (WHC), cooking loss), sensory properties (color, textures, taste, flavor, acceptability) and microstructure. Chemical composition and physical qualities data were analyzed using Anova. The differences between means were analyzed using Least Significant Different (LSD). Sensory properties data were tested using Method of Successive Interval (MSI). The results showed that the addition of carrageenan at different levels significantly $(P<0.05)$ affected water content and $\mathrm{pH}$ value. The addition of carrageenan at different levels also affected taste of chicken sausages. The addition of carrageenan at different levels had no effect on color, aroma, texture, tenderness, and acceptability. Microstructure analysis showed that addition of carragenan lead to the appearence of gel network.
\end{abstract}

(Key words: Carrageenan, Chemical composition, Chicken sausages, Microstructure analysis, Physical quality, Sensory quality)

\footnotetext{
${ }^{*}$ Korespondensi (corresponding author):

Telp. +6281347640818

E-mail: arif_fpt01@yahoo.co.id
} 


\section{Pendahuluan}

Pangan dikenal sebagai faktor risiko untuk gangguan berbagai penyakit, mulai dari penyakit jantung hingga kanker (Veldhoen dan Brucklacher-Waldert, 2012). Berbagai mikroflora yang berada di usus besar manusia secara nyata dipengaruhi oleh serat pangan. Pengaruh dari berbagai jenis serat pangan pada penghalang lendir usus, telah diterapkan terhadap hewan percobaan. Serat dan sumber serat, seperti alginat, ispaghula sekam, dedak gandum, dan karaginan diduga meningkatkan potensi pelindung penghalang lendir kolon dibandingkan dengan pangan yang kaya selulosa dan pektin (Brownlee, 2011; Shimotoyodome et al., 2001).

Properti lain yang menarik tentang berbagai efek menguntungkan serat pangan adalah kemampuan mereka untuk menurunkan kolesterol, meskipun mekanisme yang mendasari efek hypocholesterolaemic serat pangan belum terdefinisi. Akan tetapi kekurangan serat makanan dalam konsumsi harian manusia berkontribusi terhadap metabolisme gastrointestinal dan penyakit kardiovaskuler (Estruch et al., 2009). Serat pangan dapat mengurangi resiko mengembangkan gangguan kardiovaskular melalui perbaikan indeks lipid, yang menyebabkan peningkatan sensitivitas insulin dan aktivitas fibrinolitik (Brown et al., 1999).

Istilah serat pangan dikaitkan dengan karbohidrat yang berasal dari tumbuhan. Serat pangan mempengaruhi banyak gastrointestinal penting dan sistem proses tubuh. Meskipun dapat disediakan melalui suplementasi, sangat dianjurkan bahwa serat pangan tersebut sebaiknya diperoleh melalui konsumsi alami, seperti sereal, buahbuahan, sayuran atau kacang-kacangan (Galisteo et al., 2008).

Salah satu sumber serat pangan adalah berbagai jenis rumput laut. Ada banyak investigasi yang dilakukan terhadap hewan percobaan yang telah mempelajari efek hypocholesterolaemic berbagai rumput laut yang dapat dikonsumsi manusia. Polisakarida dari rumput laut, karaginan, dipergunakan sebagai tambahan sumber serat pangan karena sifat fisikokimia mereka yang unik dan keragaman struktural yang menyebabkan berbagai efek fisiologis.

Penelitian ini dilakukan untuk mengetahui pengaruh penambahan karaginan terhadap komposisi kimia, kualitas fisik, sensoris dan mikrostruktur sosis ayam yang dihasilkan.

\section{Materi dan Metode}

\section{Materi penelitian}

Penelitian ini menggunakan daging ayam bagian Pectoralis superficialis Pectoralis profundus dan Biceps femuris dibeli dari rumah potong ayam (RPA) Ayam Sakti yang berada wilayah Bengkuring Samarinda. Karaginan diperoleh dari toko kimia di Kota Gede, Daerah Istimewa Yogyakarta. Bahan tambahan berupa karaginan, tepung tapioka, minyak nabati, susu skim dan bumbu-bumbu.

\section{Metode penelitian}

Penyiapan sosis ayam. Penyiapan sosis dilakukan menurut metode (Yang et al., 2007) dengan penyesuaian. Daging ayam bagian Pectoralis superficialis, Pectoralis profundus dan Biceps femoris dibeli dari rumah potong ayam (RPA) lokal. Grinding daging menggunakan meat grinder. Bumbu dan mixer disiapkan dengan formulasi yang sudah ditentukan sebelumnya. Karaginan ditambahkan pada level 3, 6, dan $9 \%(b / b)$. Sosis kontrol juga disiapkan, tanpa penambahan karaginan. Setiap bahan dicampur dengan seksama secara manual selama 5 menit pada suhu $4-6^{\circ} \mathrm{C}$. setelah itu adonan dimasukkan ke dalam kasing sintetik (diameter $30 \mathrm{~mm}$ ) menggunakan stuffer. Sosis di-aging selama 24 jam pada suhu $4^{\circ} \mathrm{C}$ untuk memberikan kesempatan kepada bahan supaya seimbang. Adonan diambil sebanyak $10 \mathrm{~g}$ untuk dilakukan uji Stabilitas Emulsi (SE). Sosis kemudian dikukus sampai suhu di dalam sosis mencapai $80^{\circ} \mathrm{C}$. Kemudian dilakukan pengujian (komposisi kimia, kualitas fisik, dan sensoris serta mikrostruktur).

Pengujian kualitas kimia. Analisis komposisi kimia sosis ayam yang dilakukan meliputi: analisis kolagen, kadar lemak, kadar protein dan kadar air menurut metode analisis proksimat (AOAC, 1975).

Pengujian kualitas fisik. Nilai $\mathrm{pH}$ diuji dengan menggunakan elektroda glass $\mathrm{pH}$ meter mengikuti metode yang telah dilakukan oleh Tan et al. (2007). Pengukuran dilakukan sebanyak 3 kali ulangan dan nilainya direrata sebagai nilai $\mathrm{pH}$ produk daging. Pengujian keempukan menggunakan alat penetrometer. Dilakukan sebanyak 3 kali 
hasilnya direrata. Water Holding Capacity (WHC) sosis dianalisis menurut metode Hughes et al. (1997). Sampel sosis seberat $10 \mathrm{~g}$ diletakkan dalam $50 \mathrm{ml}$ tabung, dipanaskan selama 15 menit pada waterbath suhu $90^{\circ} \mathrm{C}$. setelah dipanaskan sampel didinginkan pada suhu ruang dan disentrifugasi pada $9.000 \mathrm{G}$ selama 20 menit suhu $4^{\circ} \mathrm{C}$. Supernatan dihilangkan dan endapan yang terbentuk ditimbang. WHC dihitung sebagai persentase air yang terikat menggunakan rumus berikut:

WHC $(\%)=1\{(-$ sampel setelah dipanaskan dan disentrifugasi) kadar air total X 100\%)\}

Untuk mengukur kestabilan WHC Sosis selama penyimpanan, WHC diukur setelah 1 , 20 dan 40 hari setelah penyimpanan pada suhu $4^{\circ} \mathrm{C}$. Kehilangan berat selama pemasakan (cooking loss) ditentukan dengan kombinasi pada masing-masing pengulangan menurut metode (Boles dan Swan, 1996). Berat sebelum dimasak dan berat setelah dimasak dicatat. Cooking loss dihitung berdasarkan persamaan:

Cooking loss $(\%)=(\mathrm{g}$ setelah dimasak/ $\mathrm{g}$ sebelum dimasak) $\times 100 \%$

Pengujian kualitas sensoris. Panelis adalah mahasiswa, staf Fakultas Pertanian Universitas Mulawarman. Perekrutan, seleksi dan training dilakukan berdasarkan prosedur evaluasi sensoris (Murray dan Delahunty, 2001). Tiga puluh panelis diseleksi. Sampel sosis dimasak dalam oven sebagaimana dijelaskan sebelumnya, kemudian dipotongpotong dan disajikan dalam keadaan hangat. Skor penilaian karakteristik sensoris warna (1-5: sangat terang-sangat gelap), tekstur (15: sangat kompak-sangat tidak kompak), keempukan (sangat keras-sangat empuk), rasa (1-5: sangat pahit-sangat tidak pahit), bau (1-5: sangat menyengat-sangat tidak menyengat), dan daya terima (1-5: sangat bisa diterima-sangat tidak bisa diterima). Untuk menghindari kelelahan, panelis itu dipisahkan menjadi dua kelompok, masingmasing kelompok mengevaluasi setengah dari sampel.

Pengamatan mikrostruktur sosis. Pengamatan mikrostruktur dilakukan untuk mengetahui pengaruh karaginan terhadap struktur jaringan yang terbentuk pada sosis ayam perlakuan. Tahap-tahap dalam pembuatan preparat sosis terdiri dari persiapan jaringan (sosis), dehidrasi dan penjernihan, infiltrasi parafin (parafinisasi) dan pengeblokan, pemotongan jaringan dan tahap pewarnaan. Pengambilan foto preparat dilakukan menggunakan mikroskop dengan pembesaran 10 kali. Metode pembuatan dan pengamatan jaringan mengacu pada (Shan dan Gokhale, 2004).

Rancangan percobaan. Data diuji menggunakan Rancangan Acak Lengkap pola searah terdiri dari empat level penambahan karaginan yaitu: 1 : tanpa penambahan, 2 : penambahan karaginan $3 \%, 3$ : penambahan karaginan $6 \%$, dan 4 : penambahan karaginan 9\%. Berdasarkan analisa varian (Anova) jika menunjukkan perbedaan yang nyata dilanjutkan dengan uji BNT 5\%. Untuk data ordinal yang diperoleh dari uji sensoris digunakan metode MSI (Metode Successive Interval) untuk merubah data ordinal menjadi data interval.

\section{Hasil dan Pembahasan}

\section{Pengaruh penambahan karaginan terhadap kualitas kimia sosis ayam Berdasarkan hasil pengujian} komposisi kimia sosis ayam hasil penelitian tercantum pada Tabel 1.

Tabel 1. Komposisi kimia sosis ayam dengan variasi level penambahan karaginan (chemical composition of chicken sausages at different levels of carrageenan)

\begin{tabular}{|c|c|c|c|c|}
\hline & $\begin{array}{c}\text { Kolagen (\%) } \\
(\text { collagen }(\%))^{\text {ns }}\end{array}$ & $\begin{array}{l}\text { Lemak (\%) } \\
(\text { fat }(\%))^{\text {ns }}\end{array}$ & $\begin{array}{c}\text { Air (\%) } \\
(\text { moisture }(\%))^{\text {ns }}\end{array}$ & $\begin{array}{c}\text { Protein (\%) } \\
(\text { protein }(\%))^{n s}\end{array}$ \\
\hline Level 0\% & 2,18 & 8,26 & $60,87^{\mathrm{ab}}$ & 18,35 \\
\hline Level 3\% & 2,19 & 7,83 & $62,34^{a}$ & 19,58 \\
\hline Level 6\% & 2,31 & 8,09 & $58,34^{\mathrm{ab}}$ & 18,47 \\
\hline Level 9\% & 1,84 & 7,31 & $56,62^{b}$ & 17,44 \\
\hline
\end{tabular}


Data pada Tabel 1 menunjukkan bahwa tidak terdapat perbedaan yang nyata pada semua parameter uji, kecuali pada kadar air. Komposisi kimia produk ditentukan oleh komposisi bahan penyusunnya. Komponen paling besar dalam setiap perlakuan adalah komponen daging ayam (66\%). Keseragaman bahan yang digunakan menyebabkan tidak berbedanya komposisi kimia produk sosis yang dihasilkan. Terdapat anomali pada kadar air produk, kadar air produk sosis hasil perlakuan mempunyai perbedaan, hal ini disebabkan kemampuan karaginan dalam membentuk gel, sehingga akan mempengaruhi jumlah air di dalam produk sosis ayam perlakuan. Gel yang terbentuk akan menyelimuti produk sehingga air di dalam produk tidak keluar selama pemasakan.

\section{Pengaruh penambahan karaginan terhadap kualitas fisik sosis ayam Pengaruh penambahan}

karaginan terhadap $\mathrm{pH}$ sosis. Berda hasil sidik ragam perlakuan pemberian konsentrasi karaginan memberikan pengaruh yang nyata terhadap sosis yang dihasilkan (Tabel 1). Dari hasil uji lanjut BNT taraf 5\% menunjukkan perbedaan yang nyata antara perlakuan karaginan $9 \%$ dengan perlakuan lainnya. Nilai rerata $\mathrm{pH}$ cenderung semakin tinggi sebanding dengan tingginya konsentrasi karaginan.

Dapat dilihat bahwa penambahan konsnetrasi karaginan dari level 0 sampai dengan 9\% menyebabkan peningkatan nilai $\mathrm{pH}$. Perbedaan nlai $\mathrm{pH}$ sangat dpengaruhi oleh kandungan air di dalam produk. Kandungan air di dalam produk akan mempengaruhi keseimbangan asam basa dalam produk. Jumlah air dalam produk pada perlakuan level karaginan 9\% adalah yang paling rendah $(56,62 \%)$ (Tabel 1$)$. Kadar air yang rendah ini kemungkinan menyebabkan keasaman produk meningkat sehingga nilai $\mathrm{pH}$ bertambah. Pada SNI 3820:2015, tidak ada standar $\mathrm{pH}$ yang ditetapkan.

Pengaruh penambahan karaginan terhadp Water Holding Capacity (WHC). Berdasarkan penghitungan yang sudah dilakukan, diketahui WHC sosis ayam hasil penelitian adalah tercantum pada Tabel 2.

Sejalan dengan pengurangan nilai $\mathrm{pH}$, kapasitas DIA meningkat yang terjadi seiring eksudasi cairan keluar dari produk. Sehingga jumlah air yang keluar selama pengujian akan menurun. Penelitian sebelumnya yang dilakukan oleh Ayadi et al. (2009) melaporkan bahwa pengurangan air yang lebih sedikit terjadi pada keberadaan karaginan. Akan tetapi, pada beberapa kasus penambahan karaginan terlihat tidak memberikan pengaruh, atau sangat terbatas, pengaruhnya pada DIA pada gel daging (Barbut dan Mittal, 1992).

Pengaruh penambahan karaginan terhadap keempukan (tenderness). Karaginan dengan level 0\% mempunyai nilai keempukan relatif paling besar yaitu 0,95 $\mathrm{kg} / \mathrm{cm}^{2}$. Hal ini menunjukkan bahwa keberadaan karaginan di dalam produk akan menyebabkan produk menjadi keras. Pada penelitian sebelumnya yang dilakukan Ayadi et al. (2009), penggunaan karaginan dengan level lebih tinggi dari $0,5 \%$ sudah menunjukkan adanya peningkatan yang signifikan pada hardness produk.

Pengaruh penambahan karaginan terhadap susut masak (cooking loss). Data pada Tabel 2 menunjukkan bahwa susut masak akan berkurang seiring dengan peningkatan level karaginan. Hal ini dapat dipahami, sosis dengan penambahan karaginan akan membentuk gel, sehingga eksudasi cairan dari dalam produk akan terhambat.

Tabel 2. Kualitas fisik sosis ayam dengan variasi level penambahan karaginan (physical quality of chicken sausages at different levels of carrageenan)

\begin{tabular}{|c|c|c|c|c|}
\hline & $\begin{array}{l}\text { Nilai } \mathrm{pH} \\
(p H \text { value })\end{array}$ & $\begin{array}{l}\text { DIA ) (\%) } \\
(W H C(\%))^{n s}\end{array}$ & $\begin{array}{l}\text { Keempukan }\left(\mathrm{kg} / \mathrm{cm}^{2}\right) \\
\left(\text { tenderness }\left(\mathrm{kg} / \mathrm{cm}^{2}\right)\right)^{\mathrm{ns}}\end{array}$ & $\begin{array}{l}\text { Susut masak (\%) } \\
(\text { cooking loss (\%)) })^{\text {ns }}\end{array}$ \\
\hline Level 0\% & $4,87^{c}$ & 22,23 & 0,95 & 3,92 \\
\hline Level 3\% & $4,97^{\mathrm{bc}}$ & 31,37 & 1,10 & 2,17 \\
\hline Level 6\% & $5,07^{\mathrm{b}}$ & 31,97 & 1,00 & 1,96 \\
\hline Level 9\% & $5,32^{a}$ & 32,67 & 1,10 & 1,76 \\
\hline
\end{tabular}




\section{Pengaruh penambahan karaginan pada kualitas-sensoris sosis ayam \\ Mutu hedonik warna. Hasil pengujian} hedonik dan mutu hedonik warna sosis dapat dilihat pada Gambar 1.

Berdasarkan hasil sidik ragam perlakuan pemberian konsentrasi karaginan yang diberikan tidak memberikan perbedaan yang nyata terhadap warna sosis yang dihasilkan. Warna yang dihasilkan pada masing-masing perlakuan menurut panelis adalah coklat.

Mutu hedonik tekstur. Hasil pengujian hedonik dan mutu hedonik tekstur sosis dapat dilihat pada Gambar 2.
Berdasarkan hasil sidik ragam perlakuan pemberian konsentrasi karaginan yang diberikan tidak memberikan perbedaan yang nyata terhadap tekstur sosis yang dihasilkan. Tekstur yang dihasilkan pada masing-masing perlakuan menurut panelis adalah netral.

Mutu hedonik rasa. Hasil pengujian hedonik dan mutu hedonik rasa sosis dapat dilihat pada Gambar 3.

Berdasarkan hasil sidik ragam perlakuan pemberian konsentrasi karaginan yang diberikan memberikan perbedaan yang nyata terhadap tekstur sosis yang dihasilkan. Seiring dengan penaingkatan penemabahan

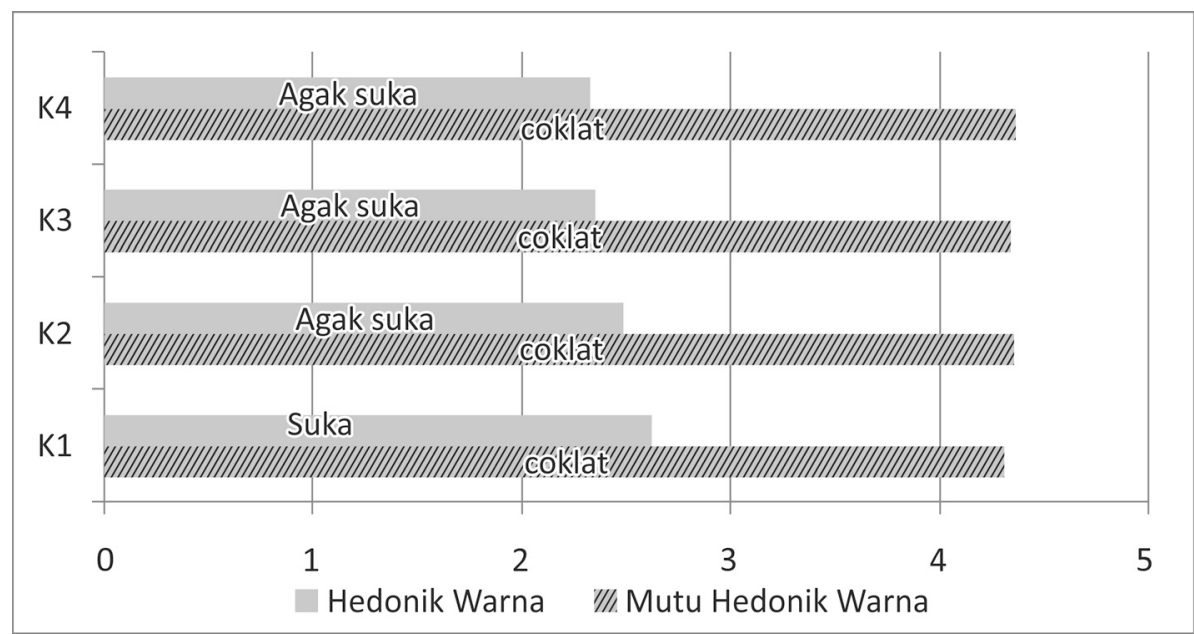

Gambar 1. Mutu hedonik warna sosis ayam dengan penambahan level karaginan $0 \%, 3 \%, 6 \%$ dan $9 \%$ (hedonic quality of color of chicken sausages with carrageenan addition levels of $0 \%, 3 \%, 6 \%$ and $9 \%$ ).

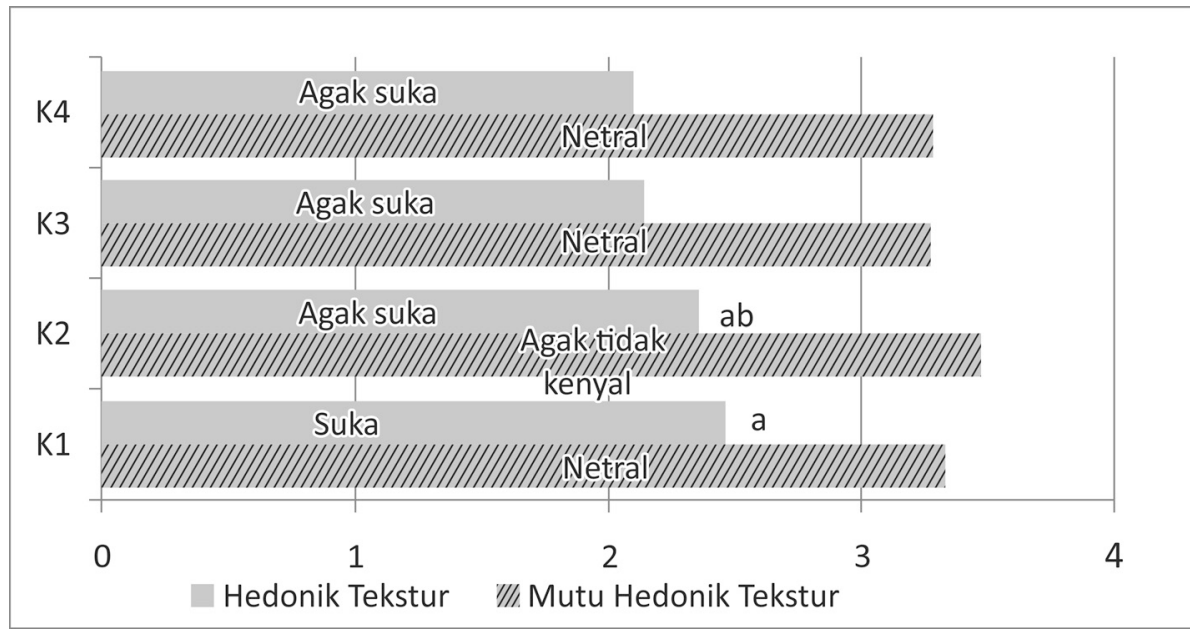

Gambar 2. Mutu hedonik tekstur sosis ayam dengan penambahan level karaginan $0 \%, 3 \%, 6 \%$ dan $9 \%$ (hedonic quality of texture of chicken sausages with carrageenan addition levels of $0 \%, 3 \%, 6 \%$ and $9 \%$ ). 


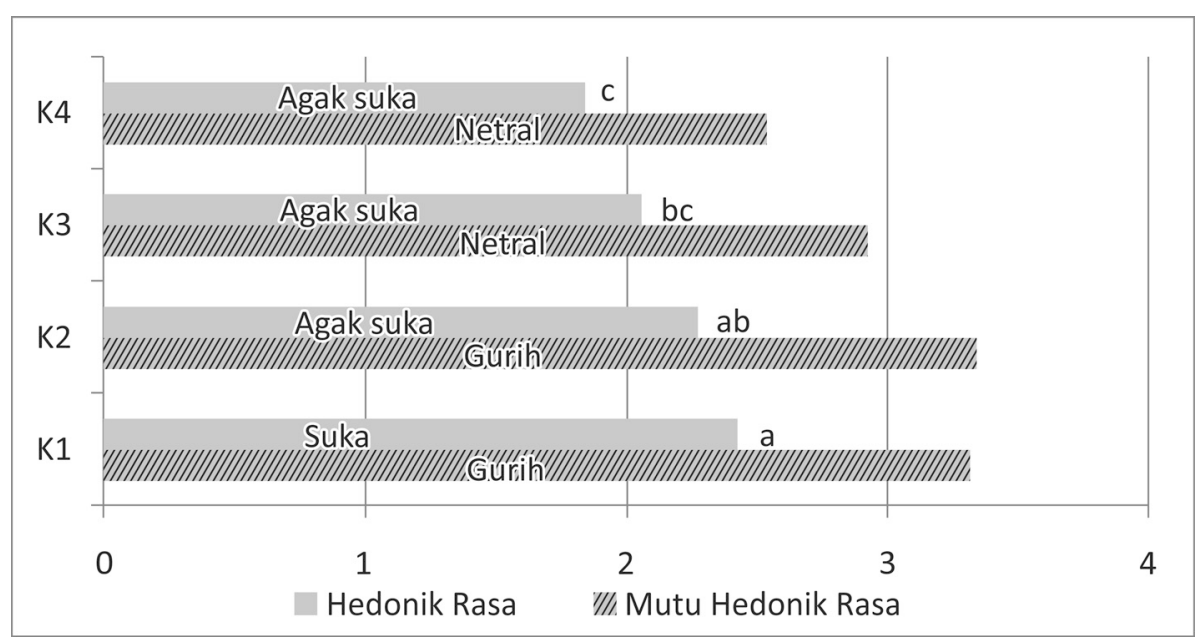

Gambar 3. Mutu hedonik rasa sosis ayam dengan penambahan level karaginan $0 \%, 3 \%, 6 \%$ dan $9 \%$ (hedonic quality of taste of chicken sausages with carrageenan addition levels of $0 \%, 3 \%, 6 \%$ and $9 \%$ ).

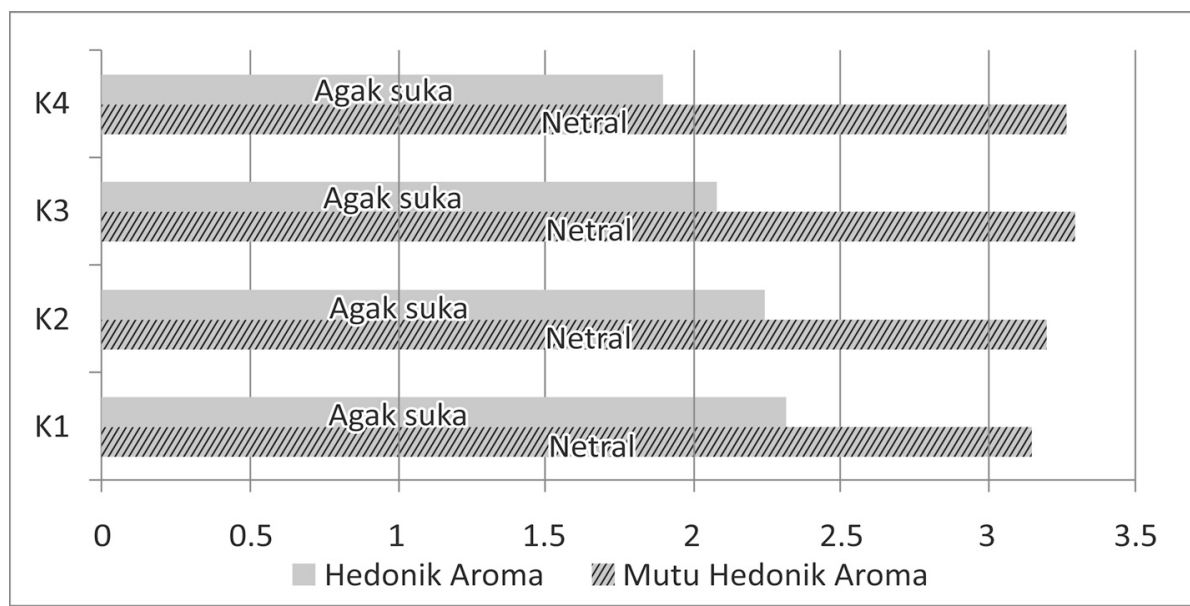

Gambar 4. Mutu hedonik aroma sosis ayam dengan level penambahan karaginan $0 \%, 3 \%, 6 \%$ dan $9 \%$ (hedonic quality of flavour of chicken sausages with carrageenan addition levels of $0 \%, 3 \%, 6 \%$ and $9 \%$ ).

level karaginan terjadi perubahan rasa dari gurih menjadi netral.

Mutu hedonik aroma. Hasil pengujian hedonik dan mutu hedonik aroma sosis dapat dilihat pada Gambar 4.

Berdasarkan hasil sidik ragam perlakuan pemberian konsentrasi karaginan yang diberikan tidak memberikan perbedaan yang nyata terhadap aroma sosis yang dihasilkan. Aroma sosis yang dihasilkan semuanya adalah netral. Panelis menyatakan bahwa aroma yang dihasilkan sosis perlakuan dalam kategori agak suka.

Daya terima. Hasil pengujian hedonik dan mutu hedonik daya terima sosis dapat dilihat pada Gambar 5.

Berdasarkan hasil sidik ragam perlakuan pemberian konsentrasi karaginan yang diberikan tidak memberikan perbedaan yang nyata terhadap daya terima sosis yang dihasilkan.

Perbandingan kualitas sosis hasil penelitian dengan sosis komersil. Hasil pengujian perbandingan antara sosis perlakuan dan sosis komersil dapat dilihat pada Gambar 6.

Terlihat bahwa kualitas sosis perlakuan K3 (karaginan 9\%) berada di bawah sosis komersial apabila dlihat dari daya terima, aroma, tekstur, dan rasa. Kualitas warna sosis perlakuan hampir sama dengan sosis komersil. Sosis perlakuan masih memerlukan pengembangan lebih lanjut. 


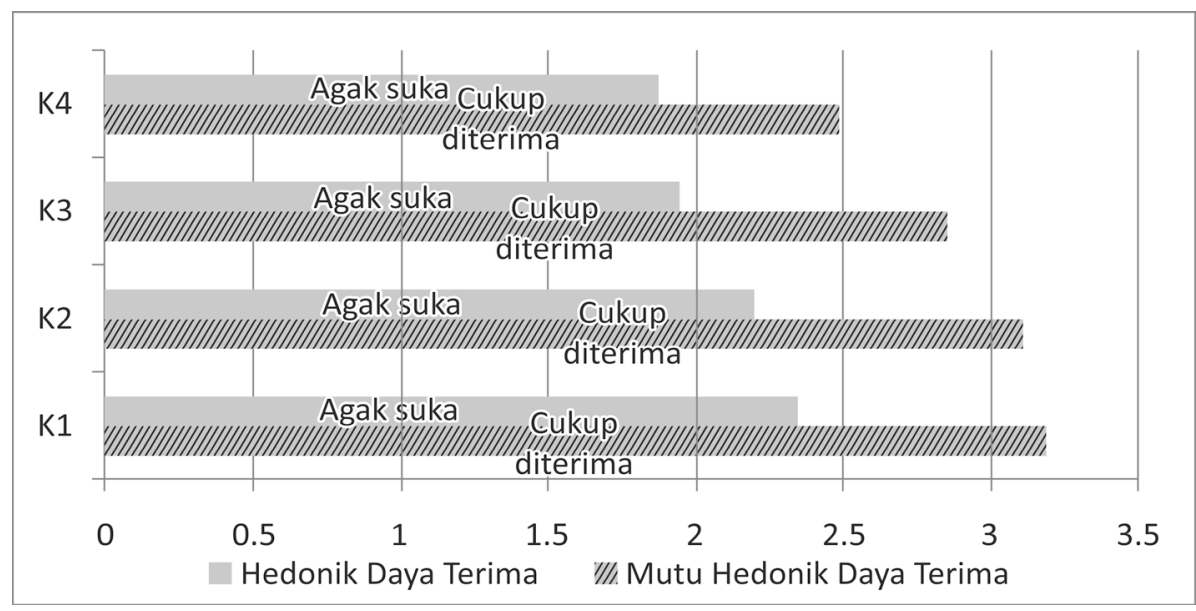

Gambar 5. Mutu hedonik daya terima sosis ayam dengan level penambahan karaginan $0 \%, 3 \%, 6 \%$ dan $9 \%$ (hedonic quality of acceptability of chicken sausages with carrageenan addition levels of $0 \%, 3 \%, 6 \%$ and $9 \%$ ).

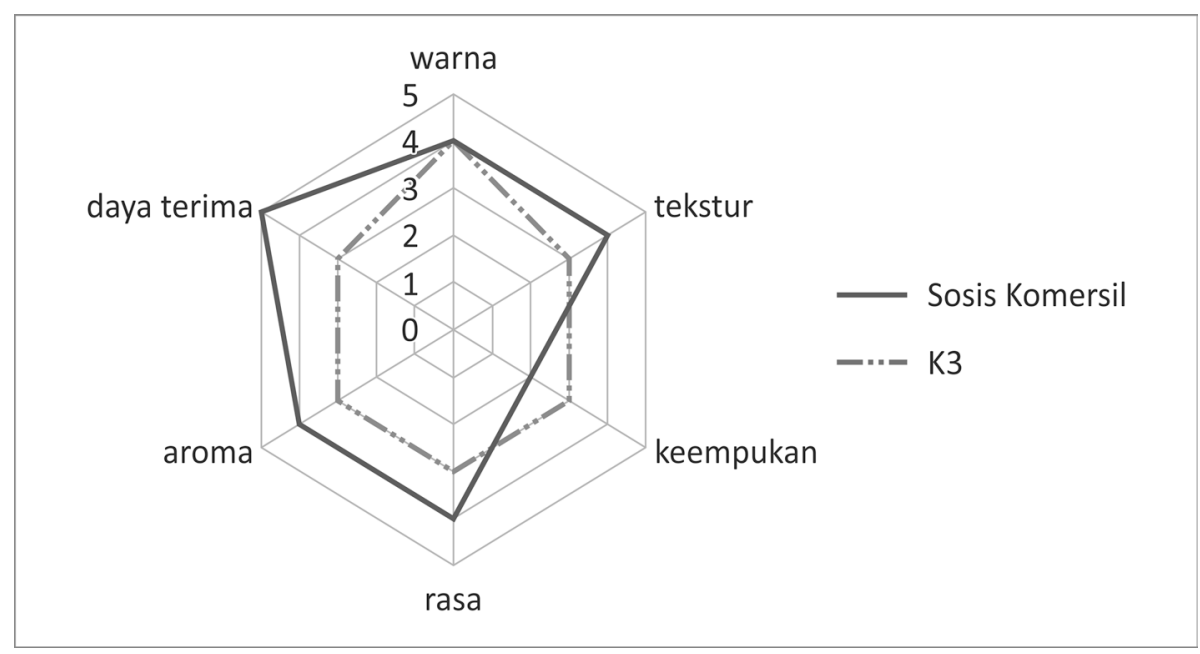

Gambar 6. Analisis mutu hedonik sosis dengan penambahan karaginan $9 \%$ dibandingkan dengan sosis komersil (hedonic quality analysis of chicken sausages with carrageenan addition level of $9 \%$ compared to comercial sausages).

\section{Kesimpulan}

Berdasarkan hasil penelitian yang sudah didapatkan, dapat diambil kesimpulan yaitu: penambahan karaginan pada produk sosis ayam memberikan pengaruh terhadap penurunan kadar air, dan berbanding lurus dengan peningkatan nilai $\mathrm{pH}$ produk. Penambahan karaginan pada sosis ayam tidak mempunyai pengaruh yang signifikan pada: warna, tekstur, keempukan, daya terima, dan aroma. Penambahan karaginan berpengaruh nyata terhadap rasa sosis ayam yang dihasilkan yaitu rasa berubah dari gurih menjadi netral.

\section{Daftar Pustaka}

AOAC. 1975. Official Methods of Analysis. The Association of Official Analytical Chemists. $12^{\text {th }}$ edn. W. Horwith (ed). Washington, DC.

Ayadi, M. A., A. Kechaou, I. Makni and H. Attia. 2009. Influence of carrageenan addition on turkey meat sausages properties. J. Food Engineering 93: 278-283.

Barbut, S. and G. Mittal. 1992. Use od carrageenans and xanthan gum in reduced fat breakfast sausages. Lebensmittel Wissenschaft Technologie 25: 509-513. 
Boles, J. A. and J. E. Swan. 1996. Effect of post-slaughter processing and freezing on the functionality of hot-boned meat from young bull. Meat Sci. 1740: 7679.

Brown, L., B. Rosner, W. W. Willett and F. M. Sacks. 1999. Cholesterol-lowering effects of dietary fiber: a metaanalysis. Am. J. Clin. Nutr. 69: 30-42.

Brownlee, I. A. 2011. The physiological roles of dietary fibre. Food Hydrocolloids 25: 238-250.

Estruch, R., M. A. Martínez-González, D. Corella, J. Basora-Gallisá, V. RuizGutiérrez, M. I. Covas, E. Ros. 2009. Effects of dietary fibre intake on risk factors for cardiovascular disease in subjects at high risk. J. Epidemiology Comm. Health 63: 582-588.

Galisteo, M., J. Duarte and A. Zarzuelo, 2008. Effects of dietary fibers on disturbances clustered in the metabolic syndrome. J. Nutr. Biochem. doi:10.1016/j.jnutbio.2007.02.009

Hughes, E., S. Cofrades and D. J. Troy, 1997. Effects of fat level, oat fibre and carrageenan on frankfurters formulated with 5, 12 and $30 \%$ fat. Meat Sci. doi:10.1016/S03091740(96)00109-X.

Murray, C. M. and I. A. B. Delahunty. 2001. Descriptive sensory analysis: past, present and future. Food Res. Int. 34: 461-471.
Shan, Z. and A. M. Gokhale. 2004. Digital image analysis and microstructure modeling tools for microstructure sensitive design of materials. Int. J. Plasticity 20: 1347-1370.

Shimotoyodome, A., S. Meguro, T. Hase, I. Tokimitsu, T. Sakata. 2001. Sulfated polysaccharides, but not cellulose, increase colonic mucus in rats with loperamide-induced constipation. Digestive Diseases Sci. 46: 14821489.

Tan, F. J., F. Y. Liao, Y. J. Jhan and D. C. Liu. 2007. Effect of replacing pork backfat withyams (Dioscoreaalata) on quality characteristics of Chinese sausage. J. Food Engineering 79: 858863.

Veldhoen, M. and V. Brucklacher-Waldert, 2012. Dietary influences on intestinal immunity. Nature Reviews Immunology. doi:10.1038/nri3299.

WHO. 2013. Cardiovascular diseases (CVDs). World Health Organization. Retrieved from http://www.who.int/ mediacentre/factsheets/fs317/en/.

Yang, H. S., S. G. Choi, J. T. Jeon, G. B. Park and S. T. Joo. 2007. Textural and sensory properties of low fat pork sausages with added hydrated oatmeal and tofu as texture-modifying agents. Meat Sci. 75: 283-289. 